\title{
Memórias de ex-dirigentes das Ligas Camponesas na Paraíba
}

\author{
Thelma Maria Grisi Velôso*
}

Este artigo sobre as Ligas Camponesas na Paraíba é fruto de uma pesquisa mais ampla que se constitui como Tese de Doutorado em Sociologia. ${ }^{1}$ Através da análise de discurso de três entrevistas semi-estruturadas com ex-dirigentes da Liga de Alhandra ${ }^{2}$ - uma entrevista com o ex-presidente, uma outra com o ex-vice-presidente e uma com um ex-fiscal objetiva-se submeter à reflexão as memórias sobre esse movimento social rural.

Em primeiro lugar, faremos algumas considerações históricas sobre o movimento a partir de uma revisão bibliográfica. Num segundo momento, nos ocuparemos da análise das memórias dos referidos entrevistados.

\section{As Ligas Camponesas: \\ breve retrospectiva histórica}

Em busca da história sobre as Ligas Camponesas nos deparamos com as seguintes considerações: com o aprofundamento das relações capitalistas no campo iniciou-se um processo de expropriação e expulsão dos moradores. Vale salientar que existiam os moradores de condição e os moradores foreiros. Os primeiros se caracterizavam pela obrigação de trabalhar

* Professora Titular do Departamento de Psicologia da Universidade Estadual da Paraíba - UEPB.

1 Velôso (2002). A tese foi orientada pela Profa. Dra. Dulce Consuelo Andreatta Whitaker.

2 Alhandra: município que se localiza no litoral sul da Paraíba. 
para a propriedade em troca de um local para morar. Desse modo, além de dar dois ou três dias de trabalho gratuito (o cambão) trabalhavam outros dias que podiam ser pagos. Havia os moradores de condição com sítio (área de terra da propriedade onde os moradores podiam desenvolver uma agricultura de subsistência) e os moradores de condição sem sítio Os moradores foreiros, por sua vez, não eram obrigados a vender sua força de trabalho. Tinham acesso a um sítio (no qual desenvolviam uma agricultura de subsistência), pagavam o foro anual (aluguel pago em dinheiro) e, muitas vezes, davam alguns dias de trabalho gratuito - o cambão (Palmeira, 1976). Após o final da Segunda Guerra Mundial - com a valorização do açúcar no mercado internacional estimulando os proprietários a aumentarem a área de cultivo e de produção - muitos senhores de engenho que tinham recorrido ao foro voltaram às suas atividades agrícolas ou então receberam das usinas melhores ofertas de renda para sua propriedade, expulsando, assim, os foreiros de suas terras, indenizando-os, ou só lhes dando direito às lavouras temporárias. Em alguns casos, as usinas permitiram que os foreiros ficassem nos sítios, contanto que destruíssem os pomares, colhessem as lavouras e se tornassem plantadores de cana (Azevedo, 1982).

As formas tradicionais de trabalho começaram a ser modificadas. Assim, as terras que eram cedidas aos moradores e aos lavradores ${ }^{3}$ foram ocupadas pela cana-de-açúcar. Em alguns casos, permitia-se que os moradores plantassem, mas os sítios eram de tamanho reduzido e situados em terras cansadas. Além disso, exigiam-se deles de cinco a seis dias de serviço por semana, impedindo-os, desse modo, de trabalharem em suas lavouras. Noutros casos, negavam o direito ao sítio onde desenvolviam a cultura de subsistência. Por outro lado, a categoria dos lavradores foi extinta, tornando-se, então, assalariados da cana. Vale sublinhar que este processo ocorreu de uma forma muito lenta. "Tanto é que, no final dos anos 50 e início dos anos 60, várias décadas após a instalação das primeiras usinas, o sistema de morada ainda vigorava com grande força na Zona da Mata (paraibana), preservando sua característica secular de exploração: o cambão" (Moreira \& Targino, 1997, p. 63, grifo nosso).

3 Lavradores: eram proprietários ou arrendatários de um pedaço de terra onde cultivavam sobretudo a cana-de-açúcar e a forneciam para os engenhos (Andrade, 1986). 
Para autores como Azevedo (1982) as Ligas eclodem nesse contexto de mudanças estruturais no setor canavieiro. Segundo o referido autor, as mudanças desencadeadas pela Revolução de 1930 foram responsáveis pela transformação da formação social agro-exportadora brasileira numa formação industrial-dependente, passando a reprodução da economia brasileira a ser governada pela reprodução do capital industrial. Não se tratou de uma revolução burguesa, mas de uma conciliação conservadora, sem um compromisso social e político com a mobilização popular que desembocasse numa transformação da estrutura da propriedade agrária ou do bloco do poder. Houve, portanto, uma vinculação entre o capital industrial e os setores agro-exportadores. Enquanto 1930 representou uma ruptura entre as classes dominantes, em 1932, com o episódio constitucionalista de São Paulo, e na Constituinte de 1934, houve uma recomposição entre as várias frações da burguesia agrária em torno de um Estado que, posteriormente, será assegurado pela ditadura do Estado Novo. Este assumirá um papel de "árbitro" entre os interesses da classe dominante, isto é, entre agrários e não-agrários.

Aos poucos, com o apoio do Estado, a burguesia industrial adquiria posição econômica e se beneficiava através de um conjunto de políticas estatais. Com a deposição de Vargas, em 1945, o Estado se vê diante da necessidade de incorporar politicamente os interesses populares. Desse modo, para garantir a legitimidade popular, o Estado incorpora os assalariados por meio do sistema partidário e da estrutura sindical vinculada ao Governo. Nesse processo, o Estado transforma-se de autoritário em populista. Se, por um lado, o Estado se dispunha a incorporar as massas urbanas ao sistema político - o que, segundo o aludido autor, instituía uma "participação controlada" e constituía as bases de dominação do bloco industrial-agrário -, por outro, excluía política e socialmente os camponeses e trabalhadores rurais.

Com relação à organização política dos camponeses consta que em 1945 surgiram as primeiras Ligas, caracterizadas como associações civis que mobilizavam e organizavam camponeses e trabalhadores rurais, tendo como base o Código Civil, procurando contornar as dificuldades burocráticas colocadas à criação dos sindicatos rurais, porém estas foram reprimidas. Segundo Aued (1986), essa organização, apoiada e engendrada pelo Partido Comunista Brasileiro (PCB), não pretendia se transformar em um movimento agrarista, mas viabilizar, como objetivo principal, a 
aliança operário-camponesa, no sentido de realizar a revolução democrático-burguesa, anti-feudal e anti-imperialista.

Concordamos com Rangel, que faz uma crítica às leituras propostas por Azevedo e Aued a respeito do movimento, argumentando que estes últimos, mediante a necessidade de submeter a experiência das Ligas à análise marxista, terminam aprisionando a experiência social dentro de uma tradição teórica - pensam a experiência como produto de uma teoria - e minimizam as experiências e o projeto político dos camponeses. Parece-nos que é preciso analisar as Ligas como resultado das "confluências de vários projetos políticos, de vários e sistemáticos empreendimentos, e que num momento propício, esses investimentos tornaram possível a emergência da Reforma Agrária como um problema nacional” (Rangel, 2000, p. 335).

Vale sublinhar, no entanto, que no período de 1948 a 1954, poucas foram as associações civis que sobreviveram no meio rural. Porém, é importante registrar que: em setembro de 1953, ocorreu a $1^{a}$ Conferência Nacional de Trabalhadores Agrícolas, realizada simultaneamente em São Paulo, Paraíba e Ceará; em agosto de 1954, ocorreu o $1^{\circ}$ Congresso Nordestino de Trabalhadores Rurais, realizado na cidade de Limoeiro (PE). Esse congresso se caracterizava como um movimento preparatório regional para a $2^{\text {a }}$ Conferência Nacional que ocorreria no mesmo ano, em São Paulo. Tais congressos objetivavam institucionalizar, como órgão de defesa e representação dos camponeses, as antigas entidades remanescentes da década de 40. Nesse sentido, durante a $2^{\mathrm{a}}$ Conferência Nacional, foi criada a União dos Lavradores e Trabalhadores Agrícolas do Brasil (ULTAB). Havia, portanto, uma mobilização e organização no sentido de lutar, dentre outras reivindicações, pela reforma agrária, pela previdência e pelo seguro social no campo (Azevedo, 1982). Em Pernambuco, as tentativas de organizar associações ou qualquer outro tipo de organização eram violentamente reprimidas. Entretanto, em 1955, foi criada, no Engenho Galiléia (município de Vitória de Santo Antão), a Sociedade Agrícola de Plantadores e Pecuaristas de Pernambuco (SAPPP), que ficou conhecida como Liga Camponesa de Galiléia (Azevedo, 1982). Vale acrescentar que esta também ficou conhecida como a Liga-mãe (Aued, 1986).

A versão mais conhecida é a de que a SAPPP foi fundada como associação beneficente, objetivando criar um fundo mútuo de ajuda para financiar caixões mortuários. Azevedo se contrapõe a essa versão, afir- 
mando que essa visão escamoteia o empenho do PCB, desde a década de 1940, de rearticular as Ligas, no campo. Portanto, a SAPPP do Engenho Galiléia seria o resultado dessas atividades políticas. ${ }^{4}$ Aued (1986) também reitera a influência do PCB no ressurgimento das Ligas, argumentando que, justamente nesse período, o partido começou a capacitar teoricamente seus militantes e sugerir que estes se engajassem nos trabalhos de massa, o que se evidencia na participação do Partido nos encontros e congressos acima ressaltados.

O processo de luta pela permanência na terra e manutenção da SAPPP fez com que os camponeses buscassem respaldo jurídico e político. ${ }^{5}$ Além disso, formou-se um comitê político interpartidário de apoio à luta dos camponeses, embrião do futuro Conselho Regional da SAPPP. Em setembro de 1955 durante a realização do I Congresso Camponês de Pernambuco, a SAPPP se transformou numa instituição estadual, sendo eleita a primeira diretoria das Ligas. Como assinala Azevedo (1982), foi nesse Congresso que nasceu a estrutura orgânica das Ligas Camponesas, ampliando-se a sua ligação com as camadas populares e os setores mais progressistas, que passaram a constituir uma base de apoio fundamental.

Os estatutos da SAPPP foram redigidos e registrados em cartório, definindo-a como uma associação civil. Ao mesmo tempo, o comitê interpartidário levava para o campo político os conflitos entre proprietários e camponeses. Rompia-se, assim, a exclusão social e política do campesinato (Ibidem). É nesse processo que as Ligas se consolidam - lutando, inclusive, pela desapropriação do Engenho Galiléia.

Se de um lado, devemos considerar a ação dos mediadores (PCB, por exemplo) nesse processo; por outro, não podemos desconsiderar que a exclusão política e social dos camponeses os impeça de construírem saberes sobre o seu mundo e suas vidas, "pois a exclusão, por mais absoluta

4 Convém lembrar que, nos anos 1940, as associações rurais mais fortes, em Pernambuco, foram as de Escada, Goiana, Pau d'Alho e Iputinga. Esta última situava-se nos arredores de Recife e era dirigida por um antigo militante comunista, José dos Prazeres. Este, em 1947, tinha se desligado do PCB, porém ainda estava à frente da Liga de Iputinga, juntamente com o seu irmão e com um dirigente comunista. Sendo assim, em 1955, teve um papel importante na organização da Liga de Galiléia. O primeiro presidente da SAPPP foi Paulo Travassos, um militante comunista (Azevedo, 1982).

5 Nesse sentido, o advogado Francisco Julião (Deputado Estadual pelo Partido Socialista, mandato assumido em 1955) se colocou à disposição da entidade, passando, então, a prestar assessoria jurídica aos camponeses. 
que seja, não significa privação de sonhos, de desejos, de valores, pelos quais eles também lutaram" (Rangel, 2000, p. 265).

As Ligas Camponesas da Paraíba, por sua vez, surgiram no bojo dos acontecimentos que marcaram os anos 1950, e também foram estimuladas por sua consolidação em Pernambuco (Benevides, 1985). A primeira Associação dos Trabalhadores e Lavradores Agrícolas da Paraíba, que passou a ser conhecida como Liga Camponesa de Sapé, foi criada em 1958. De acordo com Aued (1986), a Liga de Sapé começou através da ação de João Pedro Teixeira, por volta de 1954, e foi criada, inicialmente, no quintal de sua casa. Entretanto, ela não resistiu por muito tempo, tendo em vista a pressão do proprietário da terra. Quando ressurge, em 1958, possui uma característica nova: objetiva institucionalizar o movimento e colocá-lo nos limites da legalidade burguesa, lutando pelos direitos dos camponeses explorados. Vale acrescentar que foi fundada com o nome de Associação dos Trabalhadores Rurais de Sapé, chegando a ser considerada uma das Ligas mais poderosas do Brasil, possuindo cerca de treze mil associados.

A Associação de Sapé objetivava prestar assistência social aos camponeses e defendia os interesses dos arrendatários, assalariados e pequenos proprietários agrícolas do município de Sapé (Zona da Mata) e adjacências. Contou com o apoio de políticos de diferentes facções, estabelecendo um elo com o mundo urbano. O objetivo de romper com a exclusão social e política, que caracterizava o campesinato, tornava-se evidente (Benevides, 1985). Com as Ligas, o Poder Judiciário tornou-se mediador entre proprietários e camponeses. Além disso, a articulação com as forças políticas urbanas garantiu, de certo modo, uma proteção contra as arbitrariedades dos latifundiários. Isso não quer dizer que a violência por parte destes tenha sido neutralizada, muito pelo contrário. A Paraíba foi palco de inúmeros atos de repressão e violência contra a organização dos camponeses, através das Ligas que se espalhavam por vários municípios do Estado.

No que diz respeito ao litoral sul paraibano, existiram as Ligas Camponesas de Pedras de Fogo e de Alhandra. Segundo entrevista concedida pelo ex-presidente da Liga de Alhandra, esta foi fundada por volta de 1960 e possuía cerca de oitocentos sócios.

Em síntese, em 1961, de acordo com Bastos (1984), foi rompida a unidade do movimento camponês em todo país e, aos poucos, as Ligas 
começaram a atuar isoladamente. Desse modo, surgiram três orientações no movimento: a luta da ULTAB pela sindicalização; a atuação isolada das Ligas pela Reforma Agrária radical; e o surgimento da Igreja também lutando pela sindicalização. Entretanto, de acordo com a situação, ocorrem alianças temporárias, como a união em alguns momentos das Ligas com o PCB contra a ação da Igreja no movimento.

A organização dos trabalhadores, então legal, vai-se transformando em programa para vários patrocinadores: alguns já em cena, como o PCB (via ULTAB) e as "ligas"; outros mais novos, como a Igreja, tanto através de uma ala conservadora (Círculos Operários) ou um setor mais progressista (Ação Popular). O Estado vai tentar, cada vez mais, estender seu controle sobre a organização dos trabalhadores rurais, e cria, no mesmo ano em que se regulamenta a sindicalização, a Confederação Nacional dos Trabalhadores Agrícolas - CONTAG - a 25 de novembro de 1963. (Bastos, 1984, p. 93).

Com o Golpe de 1964, desfechou-se o "golpe fatal” sobre as Ligas. Estas foram duramente reprimidas, e seus líderes e associados perseguidos pela polícia e pelo Exército. O desaparecimento dos camponeses Pedro Fazendeiro e João Fuba (Liga de Sapé/PB), logo depois que saíram da prisão, e posteriormente o aparecimento dos dois cadáveres (Dantas, 1981) constituem uma das várias atrocidades cometidas para "silenciar" o campesinato.

\section{Memórias sobre a Liga de Alhandra: algumas possibilidades de interpretação}

Inicialmente gostaríamos de sublinhar que analisamos os discursos dos referidos entrevistados entendendo memória como um processo de reconstrução/recriação, a partir do presente, das experiências vivenciadas no passado. Assim, o que mais nos interessou foi o significado que assume hoje o acontecido para quem o viveu e o reconta. 


\section{Os objetivos do movimento e a participação dos camponeses}

Em resposta à pergunta “o que eram as Ligas Camponesas?”, o ex-presidente da Liga de Alhandra (Sr. E.) ${ }^{6}$ desenvolve um discurso que defende que a situação do campesinato, nos anos 1950, não permitia que os camponeses se inserissem no mercado e, assim, pudessem ter acesso aos bens de consumo. Em primeiro lugar, vale salientar que, ao recontar a sua história de vida, o Sr. E. não relembra que tivesse nenhuma intenção política ao vir morar em Alhandra. Veio para o município porque a cidade estava em desenvolvimento e havia uma boa perspectiva de mercado, e como, por motivos pessoais - que não eram políticos - era obrigado a sair de João Pessoa (capital do estado), tinha de tentar se estabelecer como comerciante noutra cidade e Alhandra parecia um lugar promissor. Sua inserção política é mencionada de modo muito superficial em toda a entrevista, e só falou de sua antiga filiação ao PCB, após insistência da entrevistadora.

O discurso do Sr. E. sugere que seu interesse era a melhoria de vida dos camponeses, no sentido de estes tornarem-se independentes e livres consumidores, contribuindo assim para o progresso da cidade. A relação de morada restringia a qualidade de vida dos moradores, limitando o seu poder de compra. A intenção do Sr. E. era contribuir para que os camponeses adquirissem direitos, melhorassem as condições de vida. Até porque, só assim, ele mesmo, como comerciante, progrediria e alcançaria seus objetivos. Sr. E. afirma que a Liga era para ajudar a si, ao município, ao estado e ao Brasil. O que é curioso são as hesitações, pausas e a dificuldade em enunciar tanto que o comércio ficava tolhido do progresso - "Quer dizer, o comércio ficava assim, tolhido de... de... de qualquer... de... (pausa) como é que se diz? Sem progresso." - quanto que os camponeses tinham de ter a sua categoria, tinham de se organizar. Levando-nos a pensar que talvez a própria repressão com o Golpe Militar tenha contribuído para essa imagem que pretende passar, condicionando suas lembranças. Sr. E. era filiado ao PCB que, na época, era um partido ilegal. Chegou também a ser preso com o Golpe. Desse modo, suas hesitações podem

6 Filho de pais comerciantes, nascido na Mesorregião da Mata ou Canavieira, na microrregião de Sapé e que, atualmente, é farmacêutico - dono de uma pequena farmácia na sede do município de Alhandra, local onde reside. 
ser explicadas como censuras da memória. Ou um processo consciente de ocultar seus propósitos que, à época, eram mais radicais? Por outro lado, suas lembranças também nos remetem ao projeto político burguês encampado pelo PCB, que, naquele processo, fez parte do movimento nacionalista - da vertente nacionalista econômica (Rangel, 2000).

O ex-vice presidente da Liga de Alhandra (Sr. A.), ${ }^{7}$ por sua vez, afirma que as Ligas garantiam o acesso aos direitos trabalhistas e ressalta a união - um grupo de pessoas que se uniam atrás dos seus direitos. O entrevistado refere-se ao poder do proprietário de colocar para fora os moradores quando queria e também critica esse poder. Além disso, em outro momento da sua entrevista, ao relembrar suas experiências enquanto morador, Sr. A. refere-se à precariedade das condições de vida dos moradores, a ênfase se explicita nas várias vezes em que se utiliza dos advérbios de negação, assim como de adjetivos como triste, dura. Com a Revolução de Trinta, enuncia que as coisas melhoraram mais, portanto não melhoraram totalmente, já que continuou a mesma coisa. As coisas melhoraram com as Ligas, porque estas acabam com a situação de exploração em que viviam os moradores. Porém, imediatamente, enuncia que hoje, apesar da existência dos sindicatos, os trabalhadores ainda morrem nas usinas. Portanto, a situação de exploração não mudou tanto assim.

O outro entrevistado, Sr. B., ${ }^{8}$ ao se referir a sua vida como morador em uma fazenda, enuncia que: trabalhavam o dia todo e, às vezes, quando abriam estradas, até a meia-noite; a alimentação era precária e que tinham a obrigação de trabalhar para o proprietário. No discurso do Sr. B., como no do Sr. A., há um tom de protesto, sugerindo tanto o próprio engajamento deles no movimento sindical, quanto uma forma de legitimar a própria participação nas Ligas. Um outro aspecto importante é que foram as Ligas que trouxeram a justiça para o campo. Com as Ligas, a situação muda no campo e os camponeses passam a ter direitos. Isso reitera o

7 Filho de pais que trabalhavam a terra na condição de moradores de engenho, nascido em Goiana/ Pernambuco (município vizinho à divisa com o estado da Paraíba), que exerceu, de 1963 a 1979, o cargo de presidente do Sindicato dos Trabalhadores Rurais (STR) de Alhandra, onde reside atualmente, e que já está aposentado.

8 Militante do movimento rural, fiscal da Liga e participante, há muitos anos, do STR de Alhandra. Nasceu no litoral sul, no município de Alhandra, onde hoje reside, filho de pais que trabalhavam a terra na condição de moradores, e que, mesmo aposentado, exercia, no momento da entrevista, a função de tesoureiro do STR de Alhandra. 
que já assinalamos, que as Ligas quebraram o isolamento político e social em que viviam os camponeses.

Entretanto, as lembranças do Sr. A. (ex-vice-presidente), explicitam que ele não considerava as Ligas algo positivo, chegando a sugerir que foi praticamente levado pelos outros a participar:

A: Mas não fiz muita parte da Liga não, não achei bom não, viu? Não achei bom as Liga não. Me botaram pelo meio, eu fui no meio, mas eu sempre era de fora, não gostava daquilo não. Agora, quando passou a sindicato, eu tomei conta. Do sindicato eu tomei conta, até... trabalhei vinte... trabalhei de (pausa) sessenta e dois a setenta e nove no sindicato.

P: Por que o senhor não gostava das Ligas?

A: Porque não achava bom os absurdo que fazia: invadir propriedade dos outro. Eu não achava bom aquilo... não achava bonito aquilo não. Toda vida fui contra aquilo. E até o povo da Liga não gostava de mim. Quando eu passei pra sindicato, que eu fui fundar o sindicato aqui em vinte e oito de abril de sessenta e três, foi... foi a maior confusão, está ouvindo? Porque eu não fazia parte do sindicato... das Liga não. Não achava bom as Liga não. Agora, o sindicato é lei (enfático) e eu gostava da lei do sindicato... Ainda hoje eu gosto do sindicato, não faço parte porque não posso.

É patente a postura crítica do narrador com relação às Ligas. Suas lembranças expressam-se numa reiterada negatividade: "Não achei bom as Liga não." Afirma que "não fez muita parte" das Ligas. O elemento muito ativa uma informação implícita, isto é, o pressuposto: "de algum modo fez parte". ${ }^{9}$ Essa participação é relembrada como resultado da pressão do grupo: "Me botaram pelo meio, eu fui no meio, mas eu sempre era de fora, não gostava daquilo não." Além disso, reitera enfaticamente que não gostava das Ligas, mas do sindicato, porque era lei. As lembranças do referido narrador sugerem que as Ligas não eram lei. Isso nos leva a supor que o que legitima o movimento é a sua legalidade.

9 O pressuposto é um implícito veiculado no discurso por determinados elementos (Ducrot, apud Carmo, 1997). No discurso em questão, o pressuposto é ativado pelo elemento "muito". 
É preciso considerar que sindicato é uma instituição capitalista que pode ser crítica, mas não é subversiva ao sistema, e que sua legalidade facilita a memorização. As Ligas se constituíram em algo fora da lei, "contra" o sistema e a sua ilegalidade dificulta aos narradores em geral assumir uma participação ou aprovação plena. Por isso mesmo, talvez, muitos camponeses insistam que as Ligas eram a Lei.

Vale salientar que o Sr. A., em outro momento de sua entrevista, recorda que a organização do sindicato em Alhandra contou com o forte apoio do PCB, na pessoa de Assis Lemos, e reconhece que simpatizava com o Partido, embora não tenha sido comunista. Por outro lado, a intenção do Sr. A. é demonstrar que nunca teve identificação com as Ligas e que percebeu, logo cedo, que o sindicato é que era o caminho legítimo. Desvencilha-se, assim, de qualquer ligação com o movimento, embora, nas suas lembranças, venha à tona que achava o movimento bonito:

A: Não era bom... não achava bom não, viu? Eu estava no meio, mas não achava bom não.

P: E por que que o senhor estava no meio?

A: Porque eu achava bonito! (risos)

P: O senhor não achava bom, mas achava bonito. (risos)

A: Achava bonito. Mas, os absurdos eu não achava bom não! (risos)

P: O que que o senhor achava bonito, Seu A....?

A: Eu achava bonito aquele "magote" de gente sair... os povo tudo na carreira e eu vendo aqueles povo tudo correndo e... e... e o povo passando pelas... por coisa. Saía vinte, trinta homem... Hum. (pausa) Mas eu achava os absurdo, eu achava feio, achava bonito não! (...) eu (pausa) fui daqui... me levaram daqui pra Mamanguape. (...) Moça, eu vi um absurdo lá que eu fiquei com medo! (...) Porque aquele povo de Sapé, daquele meio de mundo fazia muita derrota moça! (...) peguei avisar o povo: "Saia desse... desse ambiente, que vai haver aqui, não sei o que é, mas vai haver algum 'desmantelo'.(...)" A coisa era feia moça! (...) com poucos dia "arrebentou" a Revolução. (...) Eu tive vontade de vir "mimbora" (...) Mas, eu não conhecia o lugar, nem conhecia as estrada pra sair pra Mamanguape. Eu fiquei... fiquei com medo, lá eu fiquei com medo. Daquele povo de Sapé, aquele povo no meio do mundo era muito afoito, viu? 
Se por um lado, o Sr. A., embora não achasse bom, participava das Ligas porque achava bonito os camponeses se juntarem e se confrontarem com os proprietários na defesa dos moradores e da terra de trabalho - observemos os risos, o que denota, neste caso, satisfação - o discurso não deixa de sugerir que esteja se referindo tanto à beleza da união e da solidariedade, quanto à possibilidade de se confrontar com os proprietários que durante tanto tempo os submeteram. Por outro lado, não achava bom que, ao se confrontarem, realizassem "absurdos". De alguma forma, para o Sr. A., as Ligas exerciam alguma atração - sua beleza - o tempo todo em contraste com o seu lado feio, que terminava se sobrepondo. Mediante a audácia do povo, sobretudo o da Liga de Sapé (é enfático com relação à ousadia deles), que é considerada uma das Ligas mais fortes por todos os entrevistados, ele reconhece que teve medo. Observemos que, ao relembrar a ida para Mamanguape, além das pausas no discurso, diz inicialmente que foi e corrige imediatamente dizendo que o levaram e que só não foi embora porque não conhecia o lugar. O que denota que elementos externos influenciaram na sua capacidade de ação, eximindo-se, portanto, de responsabilizar-se pelos seus atos.

Um outro aspecto que chama atenção no discurso do Sr. A. é que ele afirma que previu que o movimento seria reprimido. Durante todo o processo já o avaliava de modo negativo. Isso legitima mais uma vez a imagem de que ele foi envolvido pelo movimento, mas logo percebeu que este não era legítimo. Perguntamo-nos porque o Sr. A., tendo sido vicepresidente das Ligas, se empenha em construir um discurso que desmerece o movimento e, além disso, minimiza o seu envolvimento. Essa posição pode refletir tanto a cisão que ocorreu no movimento, devido às divergências existentes, ${ }^{10}$ quanto a possibilidade de o processo de rememoração ser influenciado pela repressão que os camponeses sofreram com o Golpe de 1964, pois não podemos desconsiderar que a memória é recriada tanto a partir de aspectos psicológicos individuais, quanto das precedentes experiências pessoais de cada um (Portelli, 2000a).

É interessante perceber que, apesar da imagem construída pelo Sr. A., o Sr. B. (o ex-fiscal), quando relembra o seu envolvimento com o movimento, refere-se à participação efetiva e decisiva do Sr. A. nesse processo.

10 Para maiores detalhes consulte Azevedo (1982); Bastos (1984). 
Sr. B. também se refere à organização do movimento como um processo que se inicia na feira, o que também é enfatizado pelo Sr. E. (o ex-presidente da Liga). A feira era e ainda é um espaço social privilegiado: é lá que os camponeses se encontram semanalmente, seja para comercializar seus produtos, seja para fazer compras. O narrador evidencia também a propagação do movimento por meio da socialização das informações que foram passando de um para o outro e, assim, eles iam sendo convidados a participar. O Sr. B. afirma que a Liga e o sindicato era "uma coisa só", apesar de a Liga de Alhandra ter sido criada em 1960 e o STR em 1963. Notamos, ainda, que ele tornou-se um sindicalista como o Sr. A., mas nem por isso critica as Ligas. Para ele, as Ligas também eram um movimento legítimo. As lembranças do Sr. B. também sugerem um envolvimento maior do Sr. A. com o sindicato e nos fazem supor que Francisco Julião participou de sua organização. Vale ressaltar que o dia em que foi noticiada a morte de Julião coincidiu com o dia em que fomos entrevistar Sr. B., e que percebemos que essa notícia estimulou as suas lembranças, se refletindo na construção de um discurso em que o narrador se refere várias vezes à presença de Julião no movimento, assim como na Liga de Alhandra.

Por outro lado, o Sr. B., insiste nessa parceria entre as Ligas e o sindicato - "tudo misturado, os sócios das Ligas era sócio do sindicato." O seu discurso, inclusive, parece que mistura as lembranças sobre um e outro: está falando sobre as Ligas, depois se refere aos sindicatos e, em seguida, às Ligas. A insistência na parceria entre Ligas e sindicato pode também ter sido fruto da repressão: um modo que a memória encontrou de legitimar as Ligas através dos sindicatos que foram legalizados pelo Estado. Porém, também nos perguntamos como a cisão entre "julianistas" (Ligas) e o PCB (sindicato) foi vivenciada em Alhandra e, nesse sentido, como se dava a relação Ligas/sindicato. Através das lembranças, a maioria dos narradores constrói uma imagem de convivência pacífica entre os dois. Essa imagem nos remete, também ao fato de que, na Paraíba, não houve uma segmentação do tipo "julianistas” de um lado e PCB do outro (Novaes, 1997).

Essa questão de que os sindicatos deram continuidade ao trabalho das Ligas também está presente no discurso do Sr. E. quando se refere ao envolvimento e participação dos camponeses. Segundo os narradores, a Liga de Alhandra foi fundada em 1960. Se nos basearmos na categorização 
de Azevedo (1982) ela deve ter surgido na segunda fase da prática política das Ligas (1960-62). Essa fase se caracterizou pelo aprofundamento do afastamento entre as Ligas e o PCB, devido às divergências existentes; pelo reforço da idéia de uma Reforma Agrária radical, com a ocorrência de algumas ocupações; e pelo reforço de algumas concepções foquistas, com a organização de alguns campos de treinamento guerrilheiro. Os sindicatos surgem em 1963, justamente o período em que foi fundado o STR de Alhandra. Nesse período, as Ligas perderam hegemonia para os sindicatos que surgiram com o apoio do governo populista sejam aqueles coordenados pelos comunistas, sejam os coordenados pela Igreja. Os nossos narradores não fazem essa distinção, isto é, as lembranças nos conduzem para a idéia de que a organização dos sindicatos, desde o início, era um dos objetivos das Ligas. Além disso, Ligas e sindicatos, nas lembranças, aparecem juntos - "tinha que ser sócio das Ligas e do sindicato" - remetendo-nos tanto à idéia da contemporaneidade dos dois, quanto à idéia de que a memória é um espaço no qual todos os tempos coexistem e tudo ocorre continuamente (Portelli, 2000b). Por outro lado, não podemos desconsiderar que se a Liga de Alhandra surgiu em 1960, já poderia existir, naquele período, a idéia de fundação dos sindicatos.

Com relação à participação dos camponeses, Sr. E. afirma que deviam visitá-los, explicando-lhes o que eram as Ligas, porque eles não sabiam o que queriam. A imagem que constrói dos camponeses é de que eram pessoas de tal forma despreparadas que nem sabiam o que queriam, reiterando a imagem que constrói de si como alguém que tinha mais conhecimento.

Em sua entrevista, com relação à questão da participação dos camponeses nas Ligas, o Sr. A.(o ex-vice presidente) se restringe a afirmar que, antes das Ligas, não havia nenhum tipo de organização, nem existiam direitos. Para o narrador, foi com as Ligas que os camponeses começaram a se reunir e procurar os seus direitos trabalhistas e é enfático - "só isso e mais nada." A entrevistadora pergunta pelas invasões de terra e ele nega a sua existência, contradizendo o que tinha afirmado antes. É evidente que não está estimulado para falar sobre as Ligas.

Sr. B., por sua vez, ao se referir à participação dos camponeses nas Ligas, parece não ter nenhum tipo de resistência, pois assume, inclusive, a pressão que eles faziam em cima dos proprietários e seus prepostos "na lei ou na marra". Sr. B. enfatiza a realização das reuniões, como um 
espaço de participação e organização do movimento. Tais reuniões ocorriam tanto na feira, quanto nas propriedades e na sede das Ligas. As lembranças são marcadas pela relevância da união no processo de luta e resistência, denotando a sua importância para a organização dos camponeses. Tal importância é expressa no uso dos termos "união" - usado cinco vezes - e "unir". Por outro lado, já que os proprietários eram quem queria destruí-los, os camponeses, portanto, se defendiam. Os proprietários passaram a ter medo dos camponeses, mesmo que estes ainda não estivessem bem unidos, o que reforça a idéia de que os camponeses, mesmo com o mínimo de organização, foram capazes de amedrontá-los. Nesse sentido, em outro trecho de sua entrevista, Sr. B. afirma que os proprietários tinham tanto medo deles que os vigias nem cobravam o pagamento do dia de cambão, acrescentando, ainda, que o medo foi tão grande que os proprietários deram graças a Deus quando houve o Golpe. No entanto, Sr. B. também afirma que eles só eram capazes de atemorizar os proprietários porque estavam unidos e eram muitos - "sessenta, setenta, cem, duzentos homens..." - e quando perguntado como resolviam responde que a participação também se dava através dos confrontos com os proprietários e seus prepostos em defesa dos moradores - o que também exigia união. Sr. B. faz questão de enfatizar que nunca mataram ninguém, nem tiraram sangue. Os dirigentes orientavam para que eles se defendessem, e até matassem se algum dos camponeses fosse morto, mas sempre em legítima defesa, ou seja, de acordo com a lei - "as Ligas era uma lei".

Ressalte-se, ainda, que a imagem veiculada pelo Sr. E. como aquele que orientava e instruía os camponeses também está presente nas colocações do Sr. B. A diferença é que o Sr. E. faz questão de afirmar que não existia nenhuma orientação para que os camponeses se impusessem pela força, ao contrário do que relembra o Sr. B.

A responsabilidade pelo movimento que o Sr. B. confere aos dirigentes se explicita em resposta à pergunta por que os camponeses participavam das Ligas. O desejo de garantir melhorias motivou a participação. Eles lutavam pelo fim da "escravidão" - pelo fim do cambão, pela "liberdade". Sr. B. responsabiliza a direção pelo fim do movimento, a qual não soube conduzi-lo, pois, se soubesse, teriam vencido. Portanto, o movimento não foi vitorioso. O não saber conduzir o movimento está diretamente ligado ao fato de terem invadido terra: "Invadia, atirava em gente, matava vigia, dava em vigia, e era aquela coisa... (em tom baixo)". O tom 
baixo ao enunciar "e era aquela coisa...", não desconsiderando que é um modo de expressão muito comum na fala coloquial, nos remete a questionar a que coisas o Sr. B. se refere e se essas coisas foram censuradas pela memória. Por outro lado, é enfático ao afirmar que eles não faziam isso, portanto não podem ser responsabilizados pelo fim do movimento. Entretanto, afirmar que não fizeram, contradiz, de certo modo, o que elucidamos anteriormente, isto é, que ele admite que não mataram ninguém, mas bateram em administradores e vigias. Supomos que, se a intenção do discurso é responsabilizar as invasões, mortes etc. como determinantes pelo fim e conseqüente derrota das Ligas, e como eles não são responsáveis por isso e sim os dirigentes e os filiados de outras Ligas, eles não cometeram esses atos. O desejo de não se sentir responsável, ou o desejo de se mostrar "correto" é que parece ser determinante nesse momento do processo de rememoração.

No discurso do Sr. A. (o ex-vice-presidente), o que motivava a participação dos camponeses nas Ligas era poder ter direito à terra de trabalho. Ele se refere aos maltratos dos proprietários e, enfaticamente, lhes atribui a responsabilidade pela organização dos moradores. Como é comum no seu relato, confere ao outro a responsabilidade pelo envolvimento com as Ligas, tanto dele quanto dos outros, procurando sempre eximir os camponeses da responsabilidade com o movimento. Através de enunciações como "foram levados" e "não foi do gosto do povo não", o narrador sugere, mais uma vez, que os camponeses eram "inocentes", pois foram obrigados a participar da luta. Em outras palavras, a situação de exploração provocou a organização.

\section{As conseqüências positivas e negativas das Ligas}

Nas lembranças dos nossos entrevistados, as Ligas, cujo objetivo principal era a luta pelos direitos, tiveram também os seus desdobramentos. Nesse sentido, Sr. A. argumenta que as Ligas deixaram de positivo os direitos; em seguida, quando vai se referir ao que deixou de negativo, desqualifica-as usando o diminutivo: "Um tiquinho de direito desse tamanhinho que o homem tem". Por outro lado, a obtenção desses direitos restringiu a possibilidade de se conseguir terra de morada e muitos tiveram de migrar. Seu discurso sugere também que pode ser que esteja entendendo o termo negativo como nulo e, por conseguinte, ausência de 
locais onde se consiga uma morada. Desse modo, Sr. A. considera que as conseqüências positivas das Ligas foram justamente as que se ligam ao fato de ter deixado garantidos os direitos do povo, no que diz respeito às regras de morada, e que as conseqüências negativas foram a perda da terra de morada. Essa colocação nos leva a supor que "se de um lado deu, do outro lado tomou".

Sr. E. (o ex-presidente da Liga), por sua vez, evidencia que o que as Ligas deixaram de positivo foi justamente esclarecer as autoridades sobre a importância da Reforma Agrária para o desenvolvimento do país. Nesse sentido, o Sr. E., mais uma vez, dá ênfase ao desenvolvimento como um dos objetivos das Ligas, o qual é entendido enquanto garantia de maior produtividade, como a possibilidade de trazer lucros para a nação, desenvolver o comércio e trazer melhorias para o povo. Tais colocações se aproximam do projeto político burguês. Por outro lado, nos perguntamos novamente se a sua postura enquanto comunista era essa ou se trata-se do próprio processo de recriação das lembranças, no qual a sua posição foi redimensionada, inclusive, por conta da repressão sofrida, pois afinal ele foi comunista, não é mais.

Em relação ao que as Ligas deixaram de negativo, o Sr. E. faz uma crítica ao movimento, uma vez que aponta como ponto negativo a rapidez com que ele foi conduzido, sem respeitar os limites da sabedoria do povo. Segundo o narrador, o povo não tinha aquela sabedoria, sugerindo que se tratava de uma sabedoria específica. Observemos que hesita ao enunciar que o povo não tinha aquela sabedoria, e que é sugestivo ao usar muitos advérbios de negação: “Quando não era possível, porque o povo não... não... o povo não tinha... não... não tinha... não tinha... a... aquela... aquela... aquela sabedoria (enfático).” Isso parece sugerir que o que realmente faltava no povo e que não parece ser tão fácil de enunciar seria a sabedoria, dada a forma enfática como termina enunciando-a. E, nesse sentido, diz em seguida, que o povo era "grosso", mas relativiza a expressão concluindo, apesar das hesitações, que o povo "ignorava tudo aquilo". Se ignorava tudo aquilo, podia não ignorar outras coisas, portanto não era totalmente ignorante.

O Sr. E., assim como o Sr. B. (o ex-fiscal da Liga), responsabiliza a direção pelo fim do movimento. Por outro lado, além de enfatizar que teria sido necessário um processo mais lento para atrair o povo, resultando num número maior de filiados, enfatiza também que isso, paralelo ao 
entendimento com as autoridades, facilitaria tudo. Como também é comum na sua entrevista, privilegia o entendimento, o acordo com as autoridades e os proprietários.

Já o Sr. B. é o único que diz desconhecer a existência de pontos negativos e enfatiza que tudo o que as Ligas deixaram foi positivo, como se observa abaixo:

B: Se deixou alguma coisa de negativo, bem entendido, não, não sei não. Porque tudo que ela fez aqui, deixou aqui pra gente foi bom. Ela não deixou nada ruim aqui pra gente. Tudo que ela deixou foi bom, ne? Deixou nossos direito, a nossa liberdade de trabalho, de morar, de tudo. Deixou o sindicato pra gente também, nê? Que hoje muita gente não... não quer... não se associa porque não quer, mas porque, quando... só vem aqui, quando está imprensado por a... por alguém, é que vem correr aqui atrás de uma... de uma ajuda. Mas a gente está de braços aberto pra receber, nee? Aí, isso que ela deixou pra gente, ela não deixou nada de... aqui pra gente não deixou nada de negativo. Tudo que ela deixou foi positivo pra gente.

Observemos que o Sr. B. reitera, várias vezes no discurso, que as Ligas não deixaram nada de negativo, que tudo que elas deixaram foi bom, referindo-se aos direitos, à liberdade e ao sindicato, evidenciando a imagem dos sindicatos como dando continuidade ao trabalho das Ligas. As Ligas são associadas às conquistas dos direitos e da liberdade, remetendo-nos ao fim do cambão, à liberdade "de tudo", portanto liberdade total. No entanto, parece que, para o Sr. B., isso não foi considerado $a$ vitória, pois, como já sublinhamos, em outro trecho de seu relato, ele sugere que não venceram.

\section{A influência do PCB e da Igreja}

A influência do PCB é entendida pelo Sr. E. como ajuda, como a colaboração dada pelo Partido às Ligas. Nesse sentido, a Liga de Alhandra não recebeu do PCB o apoio que receberam as Ligas mais intelectualizadas como a de Sapé, entre outras. Isso fazia com que tivesse de se empenhar muito mais no movimento, a ponto de relembrar que aquilo estava prejudicando 
sua vida pessoal, relatando o caso extremo em que, na sua ausência para resolver questões da Liga, sua esposa correu risco de vida e o seu filho recém-nascido morreu. O risco de vida e a própria perda do bebê simbolizam tanto o empenho do Sr. E., quanto a falta de apoio do Partido. Por outro lado, esse caso justifica o fato de ter se aborrecido e começado a pensar em desistir. O narrador afirma, mais de uma vez em sua entrevista, que, quando houve o Golpe, estava prestes a sair do PCB. Além disso, observando o pigarro que acompanha a enunciação do fim das Ligas com o Golpe - "Pronto, agora acabou-se mesmo, pronto (pigarreia)." - podemos pensar nas emoções que tais lembranças suscitam, pois, se de um lado o fato das Ligas terem acabado foi providencial para ele que já estava pensando em desistir, por outro, não está claro se ele desejava mesmo desistir. E até mesmo o fim das Ligas e toda repressão daí decorrente devem suscitar lembranças e emoções fortes, difíceis, duras - o Sr. E. com o Golpe foi preso.

Vale salientar que o Sr. E. atribui grande importância à Liga de Sapé, considerando-a a mais intelectualizada e a que recebeu maior apoio do Partido: “....as Ligas antigas, mais intelectualizada como a de Sapé, que foi a... a... a mãe, tinha realmente ajuda, tinha cooperativa, tinha cooperação do partido, teve... o partido ajudou." Essa importância nos leva a pensar em que medida a referida Liga foi "a mãe" que gerou as outras Ligas e que, por essa função, merecia receber o apoio do Partido.

Já para o Sr. A. (o ex-vice-presidente) os membros do Partido Comunista orientavam o movimento, e faz questão de deixar claro que eles, no entanto, não faziam parte das reuniões. É enfático com relação a isso. Podemos pensar que, para o Sr. A., existe diferença entre participar das reuniões e conversar e dirigir as pessoas. Supomos que sua intenção seja a de minimizar o poder do Partido em nível legal. Acrescente-se, ainda, que o narrador parece fazer questão de deixar claro que não era comunista, e sim do Partido Trabalhista (João Goulart também era do PTB). Entretanto, relembra a influência do deputado comunista Assis Lemos no movimento e sugere, em seu discurso que, assim como Julião em Pernambuco, Assis Lemos atuava na Paraíba, reiterando a influência do PCB na Liga de Alhandra.

O Sr. B., por sua vez, ao reconhecer também a influência do Partido, não se detém na influência do PCB no movimento, mas na forma como essa influência era representada e utilizada pelos proprietários e 
seus prepostos para prejudicar a filiação dos camponeses às Ligas. Relembra que os proprietários eram contra o movimento, porque diziam que os comunistas iam tomar as terras e tomar as mulheres e filhas dos camponeses. O narrador relembra o medo que os camponeses sentiam se negando a se filiar. Sr. B. relembra que procurava convencê-los de que estavam enganados e, nesse sentido, além de argumentar que os proprietários não queriam o que era bom para os camponeses e que os comunistas queriam garantir os direitos deles, pela lei, usava o argumento também que os comunistas queriam que eles trabalhassem. Lutavam, portanto, por uma terra de trabalho. Sr. B. evidencia que essa idéia de trabalho não é comunista, pois existe desde o início dos tempos e, sugerindo que os objetivos e necessidades deles estavam acima de opções políticas, nega o comunismo em nome do trabalho - "Isso aí não é comunista não, isso aí já vem da... da... do começo da geração, de nós trabalhar." Pelo discurso do Sr. B., podemos pensar que os camponeses aliaram-se às propostas comunistas, porque elas atendiam as suas necessidades e não por uma questão mais ampla de identificação político-partidária.

Em relação à influência da Igreja durante as Ligas, o Sr. A. relembra a tentativa da Igreja de querer mandar no sindicato. Observamos que a palavra "mandar" é reiterada quatro vezes no seu discurso, e a palavra "manda" cinco vezes. Essas lembranças parecem irritá-lo sobremaneira. Com relação às Ligas, diz que não sabe se a Igreja fazia parte, o que coincide com o discurso inicial do Sr. B. No entanto, este último relembra também que a participação da Igreja durante as Ligas foi restrita: alguns participavam e outros se negavam. Sr. B. reconhece a relevância do apoio da Igreja, argumentando que a participação dessa instituição não se comparava ao apoio que é dado hoje aos conflitos de terra e que, se tivessem recebido o mesmo apoio, na época das Ligas, tudo seria diferente. No entanto, em outro trecho de sua entrevista, assinala que não há uma relação amistosa entre a Igreja e o STR de Alhandra, e ilustra isso com o fato de o sindicato não ter apoiado os pequenos produtores de um determinado assentamento a ocupar uma terra vizinha.

Quanto ao papel da Igreja, o Sr. E. (o ex-presidente da Liga), não faz referência a desacordos entre a Igreja e o sindicato. Em seu discurso, Sr. E. enfatiza que, durante as Ligas, a Igreja foi a maior inimiga. No início do movimento, ela os ajudou, o que o aproxima do discurso do Sr. B. Embora Sr. E. acrescente, com certa hesitação, que essa ajuda foi motivada 
pelo fato de os proprietários terem demolido capelas em suas propriedades. Por fim, a sua avaliação geral da participação da Igreja nas Ligas é negativa. O discurso do Sr. E. sugere que a influência da Igreja nos sindicatos foi mais determinante que durante as Ligas. Reitera a representação de que o sindicato era "filho" das Ligas e sugere que tal representação foi veiculada pela Igreja que, embora lentamente, deu garantias para a organização deles através dos sindicatos. Sr. E. também ressalta a importância do apoio da Igreja para o movimento rural, afirmando que, se a Igreja tivesse dado, naquela época, o apoio que dá hoje, teria sido diferente - "naquela época (pausa) era uma negação". Além da pausa significativa no discurso a palavra negação sugere tanto a precariedade do apoio quanto o fato de a Igreja negar o movimento. Vale sublinhar que de acordo com alguns autores, a Igreja se posicionou contra as Ligas e apoiou a fundação dos sindicatos, numa postura de defesa contra a propagação do comunismo, apoiando inclusive o Golpe de 64. Assim, as pausas e hesitações podem denunciar esse comprometimento da Igreja com o regime que o discurso procura ocultar e que o uso da palavra "negação" termina revelando.

\section{"fim" das Ligas}

O fato de as Ligas não serem registradas ou reconhecidas legalmente é elencado como um dos motivos que fizeram com que elas fossem destruídas. Por outro lado, há quem lembre que já existia uma perspectiva de substituir as Ligas pelos sindicatos, como se observa a seguir:

E: A gente não queria água... ela também não ia ter... não ter... ia ter... não... não ia ter um... um... um... continuação assim, sem... sem... com o fim de... de nunca se acabar, não! Era lutando para que se organizasse os sindicatos (enfático). Era, era. (tosse) Então, foi justamente quando ela acabou, aí já tinha alguns sindicatos funcionando. Pelo menos aqui já tinha um. É.

É preciso enfatizar o tom altamente hesitante, presente, mais uma vez, no relato do Sr. E. quando ele se refere aos sindicatos. As hesitações, na seqüência discursiva acima, nos levam a indagar desde quando existia e até que ponto existia realmente a perspectiva do fim das Ligas em prol da organização dos sindicatos. Se nos colocarmos a questão de em que 
momento tal perspectiva veio à tona, nos remeteremos a 1963, às vésperas do Golpe, quando as Ligas perdem espaço para os sindicatos fundados tanto pela Igreja, quanto pelo PCB, com o apoio do governo populista. A memória, no entanto, parece desconsiderar essa fase na história do movimento, sugerindo que tal perspectiva existia desde a própria fundação das Ligas, desde o início do movimento. Em Alhandra foi diferente? Sabemos que uma das características da memória, como já sublinhamos, é que ela é um espaço onde todos os tempos coexistem e tudo ocorre continuamente (Portelli, 2000b). Por outro lado, o passado é recriado em função das necessidades do presente e das perspectivas de futuro. Nesse sentido, supomos que o papel que os sindicatos assumiram com o Golpe serviu e serve para legitimar a organização das Ligas e minimizar o envolvimento com estas que foram, como sabemos, duramente reprimidas, e que essas marcas da repressão seriam determinantes nesse processo de recriação das lembranças.

Por outro lado, como já explicitado, Novaes (1997) observa que, na Paraíba, durante o processo de luta, as divergências não resultaram em propostas concretas diferenciadas. Tanto uma ala como a outra recorreram, de acordo com as condições políticas, à proposta de sindicalização. E enfatiza que as divergências na Paraíba não foram responsáveis por uma segmentação do movimento, do tipo PCB (sindicatos) x Julianistas (Ligas) e assim por diante. A conjuntura foi muito mais complexa, porque a violência dos proprietários exigia que se estabelecesse uma "convivência" entre as correntes divergentes.

Em relação ao Golpe de 1964 e, por conseguinte, ao desmantelamento do movimento, Sr. E. relembra que estava em Recife (Pernambuco) e que, quando a situação amenizou, voltou para Alhandra, recebeu uma intimação e foi preso. Vale ressaltar que o Sr. E. relembra, durante a sua entrevista, que foi preso muitas vezes durante o movimento tanto pela polícia quanto pelo Exército. Quando relembra sua prisão com o Golpe, minimiza o papel repressor do Exército. Desse modo, quando o narrador se refere ao período em que esteve preso numa instituição militar (15. ${ }^{\circ}$ Regimento de Infantaria, com sede em João Pessoa), hesita em dizer que estava preso, relembrando que possuía muita liberdade e as demonstrações de apoio e solidariedade que recebeu tanto da sociedade civil, quanto dos sindicatos. Suas lembranças, portanto, minimizam a repressão sofrida. 
Sr. A., por sua vez, chega a afirmar que com o Golpe a situação ficou muito melhor. O narrador não desconhece que houve repressão com o Golpe de 1964 - vale salientar, após evidente insistência da entrevistadora - pois ele próprio, inclusive, teve de fugir. Entretanto, o que prioriza em seu discurso é que os sindicatos, com o Golpe, puderam trabalhar com o apoio e participação dos proprietários (importância da legitimação dada pelos órgãos instituídos). Por outro lado, parece não se dar conta das perdas que tiveram com essa legitimação. Além disso, minimiza a repressão sofrida quando a compara com a Revolução de Trinta.

Sr. B. (o ex-fiscal da Liga), entretanto, se refere à situação difícil que tiveram de enfrentar no pós-64. O narrador é explícito com relação às dificuldades que enfrentaram: "não tinha onde tomar pé" - perderam o equilíbrio, a sustentação - pois "morreu o cabeça" - quem orientava, guiava. Relembra que João Goulart era o "chefão" juntamente com Julião e os outros deputados. O apoio de João Goulart, enquanto presidente, era imprescindível para os deputados terem força. Inicialmente, diz que "o cabeça" morreu, depois diz que foi "tirado de circulação". Com essa enunciação pode indicar que: a memória não consegue precisar bem os acontecimentos; que não sabe quem foi tirado de circulação; ou que ser "tirado de circulação" significa também uma morte; que a memória estaria se reportando à queda de João Goulart e a expulsão de Julião e de outros do país; e/ou que a notícia veiculada, no dia da entrevista, da morte de Julião (como já explicitado) também influenciou o discurso.

Sr. B. explicita também que, nesse contexto de "perda de força", os proprietários resolveram se vingar, mas não alcançaram seus propósitos por conta do sindicato. Daí se explicita o papel do sindicato como aquele que deu proteção, apoio e continuidade ao movimento, no sentido de garantir os direitos dos trabalhadores. Sr. B. afirma que as Ligas acabaram com o cambão - eles não aceitaram mais - e os sindicatos substituíram as Ligas, dando continuidade à luta pelos direitos do trabalhador rural.

As lembranças do Sr. B. convergem para a idéia de que, depois das Ligas, não houve mais cambão - "acabou-se por completo". Essa idéia é discutível. Por outro lado, a história oral nos informa não só sobre os fatos, mas sobre o que estes significam para quem os viveu e os reconta; não só sobre o que as pessoas fizeram, mas sobre o que queriam fazer ou crêem que tenham feito (Portelli, 1985). 


\section{Considerações finais}

Propomo-nos, neste artigo, a realizar uma reflexão sobre as Ligas Camponesas na Paraíba a partir das lembranças dos ex-dirigentes da Liga de Alhandra - PB.

Nesse sentido observamos que, além da crítica explícita às relações de morada, essas lembranças enfatizam o fim do cambão como bandeira de luta, a representação das Ligas como uma luta pelos direitos e a representação dos sindicatos como dando continuidade ao trabalho do movimento. As divergências entre as diferentes facções que compunham o movimento Ligas, inclusive as divergências com relação à própria fundação dos sindicatos, não vêm à tona nas lembranças, o que corrobora as posições teóricas que defendem que, na Paraíba, as divergências não foram responsáveis por uma segmentação do movimento. Chama atenção, na reconstrução dessas memórias, o fato de o ex-presidente da Liga de Alhandra referendar os objetivos das Ligas a partir dos ideais nacionalistas de desenvolvimento e progresso.

Além disso, tanto ele quanto o ex-vice-presidente criticam, no confronto com os proprietários, a "ousadia" de Ligas como a de Sapé (a primeira Liga que foi fundada na Paraíba e da qual fazia parte João Pedro Teixeira). A imagem que eles veiculam da Liga de Alhandra é que esta, ao contrário de outras, procurava resolver as questões de uma maneira pacífica, buscando o entendimento com os proprietários. Essa imagem se contrapõe às lembranças de outros pequenos produtores e até de um outro membro da ex-diretoria (ex-fiscal) os quais recordam a chamada "violência" dos filiados da Liga. Tal contraposição nos remete à suposição de um trabalho da memória frente à repressão sofrida com o Golpe.

O que também chama atenção é que o ex-vice-presidente, através de suas lembranças, realiza uma crítica ferrenha às Ligas, e recorda a sua filiação como sendo o resultado da pressão do grupo. Critica as Ligas por quererem invadir terras alheias e, em contrapartida, afirma sua admiração pelo sindicato enquanto lei e, nesse sentido, relembra que fundou o Sindicato de Alhandra e saiu logo da Liga. Suas lembranças conduzem para o fato de que nunca se identificou com o movimento e que percebeu, logo cedo, que o sindicato era o caminho legítimo, sugerindo, novamente, um trabalho da memória frente à repressão. 
Com relação à influência do PCB e da Igreja no movimento, relembram do apoio dado pelo Partido, mas também que esse apoio era bem menor se comparado ao recebido por outras Ligas, como a de Sapé. A Igreja, por sua vez, é relembrada como tendo dado mais apoio aos sindicatos do que às Ligas. Por outro lado, há críticas no que se refere às tentativas da Igreja de interferir no STR de Alhandra.

Um outro aspecto a ser sublinhado é que as lembranças conduzem para o fato de que foi a direção do movimento a responsável pelo fim do mesmo, na medida em que não soube conduzi-lo. E no que diz respeito ao Golpe, as lembranças com relação à repressão é minimizada: o ex-presidente relembra que, em sua prisão, após o Golpe, possuía muita liberdade e recebeu muito apoio da sociedade civil. O ex-vice, por sua vez, relembra que não foi preso e que a situação melhorou com o Golpe, na medida em que os sindicatos puderam desenvolver o seu trabalho. O papel do sindicato como aquele que protegeu o trabalhador após o Golpe também é reiterado. Porém, nas lembranças do ex-fiscal são enfatizadas as dificuldades enfrentadas com a repressão. Parece-nos que o cuidado com "as garras" da repressão está muito mais presente no discurso do expresidente e do ex-vice da Liga de Alhandra, o que é compreensível, tendo em vista as penalidades maiores a que estiveram sujeitos.

\section{Referências bibliográficas}

ANDRADE, Manoel. C. A terra e o homem no Nordeste: contribuição ao estudo da questão agrária no Nordeste. $5^{\text {a }}$ ed. São Paulo: Atlas, 1986.

AUED, Bernardete. W. A vitória dos vencidos: Partido Comunista Brasileiro e ligas camponesas 1955-64. Florianópolis: UFSC, 1986.

AZEVEDO, Fernando. Antonio. As ligas camponesas. Rio de Janeiro: Paz e Terra, 1982.

BASTOS, Elide. Rugai. As ligas camponesas. Petrópolis: Vozes, 1984.

BENEVIDES, Cezar. Camponeses em marcha. Rio de Janeiro: Paz e Terra, 1985.

CARMO, Sônia Irene S. Discurso, sociedade e história. Araraquara: 1997. Mimeografado.

DANTAS, Antônio. A propósito das ligas camponesas, entrevista concedida a GONÇALVES, M.C.R. Cadernos de Estudos Regionais. João Pessoa, n. 4, p. 103-121, 1981.

MOREIRA Emília R.F.; TARGINO, Ivan. Capitulos de geografia agrária da Paraíba. João Pessoa: Universitária/UFPB, 1997. 
NOVAES, Regina. Reyes. De corpo e alma: catolicismo, classes sociais e conflitos no campo. Rio de Janeiro: Graphia, 1997.

PALMEIRA, Moacir. Casa e trabalbo: notas sobre as relações sociais na plantation tradicional. Paris: 1976. Mimeografado. Apresentado como comunicação no Simpósio Le rapport au travail dans les sociétes américaines, Congresso dos Americanistas.

PORTELLI, Alessandro. Biografia di una città: storia e racconto, Terni 1830-1985. Torino: Einaudi, 1985.

. Con-verso. Stralcio dell'intervista al Prof. Alessandro Portelli. Zagabria, Istituto Italiano di Cultura, 14 marzo, 2000 (a). Mimeografado.

Le Fosse Ardeatine e la memoria: rapporto su un lavoro in corso. In: Paggi, L. (a cura) Le memorie della Repubblica. Milano: Il Saggiatore, 2000 (b). p. 89-154.

RANGEL, Maria do socorro. Medo da morte e esperança de vida: uma história das ligas camponesas na Paraíba. 2000. Campinas, Universidade Estadual de Campinas, (Dissertação de Mestrado), 2000.

VELÔSO, Thelma Maria G. Frutos da terra: memórias da resistência e luta dos pequenos produtores rurais de Camucim-Pitimbu/PB. Araraquara, Universidade Estadual Paulista, (Tese de Doutorado), 2002.

Resumo: Este artigo tem como objetivo realizar algumas considerações referentes às lembranças dos ex-dirigentes da Liga de Alhandra (Alhandra/Paraíba) sobre as experiências de resistência e luta que vivenciaram nos anos 1960. A partir da análise do discurso das entrevistas desses ex-dirigentes serão ressaltadas as lembranças referentes à origem do movimento, seus objetivos, suas conseqüências, a influência do Partido Comunista e da Igreja, seu final, com o Golpe de 1964, e a participação dos pequenos produtores em todo esse processo.

Palavras-chave: Ligas Camponesas; memória; análise do discurso.

\section{Memories of Ex-Directors of the Peasant's Leagues in Paraíba State}

Abstract: This article has as objective to accomplish some considerations regarding to the memories of the ex-directors of the Alhandra League (Alhandra / Paraíba) on the experiences of resistance and fight that they lived in the sixties. Starting from the discourse analysis of the report of those directors, it will be analyzed the memories regarding the origin of the movement, their objectives, their consequences, the influence of Communist Party and Church, its end with the coup d'etat of 1964 and the participation of the peasants in the whole process.

Keywords: Peasant's League; memory; discourse analysis. 
